\title{
FLOTATION BEHAVIOR OF SUDANESE CHROMITE ORES
}

\author{
Seifelnassr, A. A .S and Tamam, T. A. $K^{\star \star}$ \\ "Professor in Suez Canal University, Faculty of Petroleum and Mining \\ Engineering \\ ${ }^{* *}$ Lecturer in Omdurman Islamic University, Faculty of Eng. Sciences, \\ Dept. Mining Engineering
}

(Received March 20, 2011 Accepted April 8, 2011)

This study is concerned with the processing of low grade chromite ores, Ingassena Hills, Sudan, by froth flotation techniques. For this purpose, representative samples were taken from four different mines. Mineralogical examinations indicated that, the major minerals are chromite and serpentine. Olivine, iron oxides and talc have been identified as minor minerals. Adequate degree of liberation of chromite was obtained by grinding the ore to minus $180 \mu \mathrm{m}$.

Froth flotation was used to upgrade this chromite ore. Oleic acid was used as collector. Several operating parameters influencing the floatability of the Sudanese chromite ores were investigated. These include the collector and depressant dosages, pulp $\mathrm{pH}$, and conditioning time. From an ore feed grading $20.27 \% \mathrm{Cr}_{2} \mathrm{O}_{3}$, a chromite concentrate of $28.71 \% \mathrm{Cr}_{2} \mathrm{O}_{3}$ with recovery of $94.54 \%$ could be obtained by flotation at collector dosage of $0.300 \mathrm{~kg} / \mathrm{t}, \mathrm{pH} 9,2$ min conditioning time, and $20 \%$ pulp density.

\section{INTRODUCTION}

Chromium is one of the most versatile and widely used elements. Its main uses in the metallurgical, chemical, and refractory industries are well known. It is an essential element in the production of a wide variety of stainless steels, tool and alloy steels, nickel-chromium heating elements, and plating metals. Its widespread use in the metallurgical industry is attributed to its capability of enhancing properties such as resistance to corrosion or oxidation, creep, impact strengths, and hardenability.

In Sudan, Chromite ore deposits occur in the Ingassana hills in the Blue Nile region. Other occurrences had been reported at Hamissana-sol Hamed in the northern Red Sea Hills, the Nuba Mountains in southern Kordofan, Jabal Rahib northwest Sudan and Jabal El Tawil in central Butana in southern Sudan. However, the Ingassana chromite ore is considered as one of largest chromite ore deposits in Sudan [Adli, 1998].

Low-grade deposits and the fines resulting in the mining operations can not be economically used. Therefore, beneficiation of low grade and finely disseminated ores is becoming important in recent years due to the shortage of high grade ore reserves.

Although gravity methods are well known and widely used for the concentration of chromites, such techniques fail to recover chromite from the fine size fractions below approximately $100 \mu \mathrm{m}$.

Flotation offers an alternative concentration process for the separation of the fine materials and the reduction of chromium losses. However, earlier results of 
flotation of lower-grade chromite ores were inferior to those obtained by tabling [Nafziger, 1982].

There are two general types of methods for separating chromium ore (chromite) values from associated gangue minerals by froth flotation techniques. In the first method chromite ore which has been deslimed is subjected to flotation at a $\mathrm{pH}$ of 1.5 to 5.5 with a long chain fatty acid collector as reported by Havens (1946). The selectivity of the process is enhanced by adding a soluble fluoride compound such as hydrofluoric acid, sodium fluoride or sodium silicofluoride in the flotation medium. The flotation process is typically conducted by adding 0.5 to 5.0 pounds fatty acid, 0.1 to 10.0 pounds soluble fluoride ion and 1.0 to 11.0 pounds sulfuric acid per ton of ore to the aqueous treatment medium containing the chromite ore. A typical product obtained by such a process, from an ore containing $25.2 \% \mathrm{Cr}_{2} \mathrm{O}_{3}$, is a recleaner concentrate containing $41.0 \% \quad \mathrm{Cr}_{2} \mathrm{O}_{3}$ and $2.5 \% \quad \mathrm{SiO}_{2}$ with a chromium recovery of $77.0 \%$.

In the second technique [U.S. Pat. No. 3,473,656], chromite ore flotation is achieved with an undeslimed ore at a $\mathrm{pH}$ of 11.5 using a long chain fatty acid collector. The $\mathrm{pH}$ of the pulp is adjusted with $\mathrm{NaOH}$ with the pulp being dispersed by sodium silicate using carboxymethylcellulose as a depressant for silicate gangue minerals. Typically during processing, three pounds of sodium silicate, 1.0 to 3.0 pounds of tall oil, and 0.25 to 0.50 pounds of carboxymethylcellulose per ton of ore are added to the flotation cell.

From an ore containing $18.13 \% \quad \mathrm{Cr}_{2} \mathrm{O}_{3}$ and $23.98 \% \quad \mathrm{SiO}_{2}$, a flotation concentrate was obtained containing $52.16 \% \mathrm{Cr}_{2} \mathrm{O}_{3}$ and $3.72 \% \mathrm{SiO}_{2}$ with a chromium recovery of $80.0 \%$. Also, Pryor, (1965) reported studies on a Turkish chromite ore containing $30 \% \mathrm{Cr}_{2} \mathrm{O}_{3}$, associated with oxides and sulphides and gangue minerals are chiefly serpentine and olivine. When grounded to-100 $\mu \mathrm{m}$ the serpentine dominated the fines, chromite the medium particles and olivine the coarse. Strongly alkaline pulp (more thanpH10) was used, with sodium oleate and oleic acid to float the serpentine. The pulp was then rendered acidic $(\mathrm{pH} 3)$ and chromite was floated with $0.75 \mathrm{lb} /$ ton of fatty acid-amine collector. Olivine, which only floats in a neutral solution under these conditions, remained in the final tailing, the obtained concentrate grade was $45 \%$ $\mathrm{Cr}_{2} \mathrm{O}_{3}$.

Preconditioning with fuel oil permitted flotation of the chromite from the flocculated siliceous-gangue slimes. Recoveries of up to 91 percent were realized with products containing up to 45 percent $\mathrm{Cr}_{2} \mathrm{O}_{3}$ [Hunter and Sullivan, 1960]. The $\mathrm{Cr} / \mathrm{Fe}$ ratios ranged from 2.17 to 2.46. Oleic acid was used for flotation. Sodium fluoride and sulphuric acid yielded better results than dilute hydrofluoric acid when these reagents were added to free the 'flocs' from the siliceous gangue.

A process developed for one ore does not usually yield optimum results for another ore of different origin. It is thought that differences in the composition of the gangue materials, as well as in the composition of the chromium spinels, are responsible for these variations in flotation behavior. Fundamental research is required to alleviate this problem. Investigations involving the flotation of a high grade chromite sample and a high grade serpentine using sodium oleate as the collector showed [Sagheer, 1966] that the chromite can be floated at collector dosages between 0.3 and $1000 \mathrm{mg} / \mathrm{l}$. 


\section{EXPERIMENTAL}

\subsection{Materials}

\subsubsection{Chromite Ore Sample}

A chromite ore sample about ( $250 \mathrm{kgs})$ of low grade ore was collected from Chickay mines, at the Ingassana Hills. A high grade chromite ore sample $(10 \mathrm{Kg})$ and a similar high grade serpentine sample were selectively collected to investigate their flotation characteristics. Lumpy Samples, about $10 \mathrm{~kg}$ of low grade chromite ore were taken from Chickay and Romallic mines. Thin and polish sections were made for mineralogical analysis from the lumpy samples.

\subsection{Methods}

\subsubsection{Preparation of samples:}

The low grade sample $(20 \mathrm{~kg}$ ) was crushed though Jaw crusher and roll crusher, coned, quartered and divided into smaller samples of $1 \mathrm{~kg}$ each for the mineralogical and wet chemical analysis. The mineralogical properties of the ore sample were examined by ore microscopy, while chemical analysis was conducted by wet chemical assaying methods, AAS, and XRF.

Low grade Sample was prepared for flotation tests by stage crushing and grinding down to a reasonable liberation size $(0.180 \mathrm{~mm}$ particle size $)$. The ground sample was subjected to sieve analysis as shown in Table 1

Table 1: Particle size distribution of low chromite ore as feed for flotation tests

\begin{tabular}{|c|c|c|}
\hline Particle size(mm) & Weight \% & Cum.U.size \% \\
\hline$-0.180+0.076$ & 41.42 & 100 \\
\hline$-0.076+0.038$ & 13.7 & 58.58 \\
\hline-0.038 & 44.9 & 44.9 \\
\hline
\end{tabular}

\subsubsection{Flotation Tests}

For each test, a certain weight of ore sample (chromite / serpentine / chromite ore) was transferred to a 2-liter flotation cell. The sample was wetted for 5 minutes, and then the pulp $\mathrm{pH}$ was adjusted by $\mathrm{H}_{2} \mathrm{SO}_{4}$ or $\mathrm{NaOH}$. Then the depressant (sodium silicate) dosage was added, if required, then the pulp was conditioned for 2 minutes. The collector (oleic acid) dosage was then added and conditioned for $2 \mathrm{~min}$., after which the frother was added and conditioned for 1 minute. Finally the air is opened and the froth was collected until the froth is barren. Both froth and sediment were filtered, dried, weighted and analyzed. 


\section{RESULTS AND DISCUSSION}

\subsection{Chemical and mineralogical compositions}

\subsubsection{Characterization of high grade minerals}

Both the chromite and serpentine samples were cleaned by hand sorting, magnetic separation and panning, and washed with triple distilled water. After drying, the sample was ground in agate mortar to pass $250 \mu \mathrm{m}$ sieve. The measured density of chromite and serpentine were determined to be 4.6 and $2.6 \mathrm{~g} / \mathrm{cm}^{3}$ respectively. It should be noted that the true density of chromite mineral and serpentine rock is $4.5-$ $4.8 \mathrm{~g} / \mathrm{cm} 3$ and $2.5-2.6 \mathrm{~g} / \mathrm{cm} 3$, respectively. The chemical compositions of the samples determined by wet chemical analysis are given in Table 2 . Mineralogical composition of high grade chromite is chromite, magnetite, hematite and olivine, and also for serpentine are serpentine, chlorite, smectite, hematite and calcite.

Table 2: Chemical analysis of high grade chromite, high grade serpentine and low grade chromite samples

\begin{tabular}{|c|c|c|c|}
\hline Property & Chromite & Serpentine & $\begin{array}{c}\text { Low-grade } \\
\text { ore }\end{array}$ \\
\hline $\mathrm{Cr}_{2} \mathrm{O}_{3}, \%$ & 57.6 & 1.2 & 24.9 \\
\hline $\mathrm{Fe}_{2} \mathrm{O}_{3}, \%$ & 19 & 12 & 8.6 \\
\hline $\mathrm{SiO}_{2}, \%$ & 3 & 47 & 24.2 \\
\hline $\mathrm{MgO}, \%$ & 8.5 & 29 & 13.1 \\
\hline $\mathrm{CaO}, \%$ & 0.2 & 2.5 & 0.02 \\
\hline $\mathrm{Cr} / \mathrm{Fe}$ & 3.1 & 0.1 & 2.9 \\
\hline
\end{tabular}

\subsubsection{Characteristics of law grade chromite}

The examination of thin and polished sections revealed that the main minerals were chromite $\left[(\mathrm{Fe}, \mathrm{Mg}) \mathrm{O} .(\mathrm{Al}, \mathrm{Fe}, \mathrm{Cr})_{2} \mathrm{O}_{3}\right]$, serpentine $\left[(\mathrm{Mg}, \mathrm{Fe})_{3} \mathrm{Si}_{2} \mathrm{O}_{5}(\mathrm{OH})_{4}\right]$ with excess magnesium[Read,1956], talc $\left[\mathrm{Mg}_{3} \mathrm{Si}_{4} \mathrm{O}_{10}(\mathrm{OH})_{2}\right]$, and chlorite[( $\left.\mathrm{Mg}, \mathrm{Fe}\right)_{5} \mathrm{Al}\left(\mathrm{AlSi}_{3}\right.$ $\left.\mathrm{O}_{10}(\mathrm{OH})_{8}\right]$. Intercrystaline euhedral and subhedral chromite crystals are filled with unhedrall and frequently fractured serpentine crystals (Fig.1). Traces of olivine can be detected as fine grains within the serpentinite matrix as well as trace quantities of iron oxides, antigorite $(\mathrm{Mg}, \mathrm{Fe})_{3} \mathrm{Si}_{2} \mathrm{O}_{5}(\mathrm{OH})_{4}$, asbestos and talc-carbonate .These micrographs show also the relative grain size of the these components.

The revealed results from investigating of thin and polish sections and from the chemical analysis, indicated that the ore contains approximately $45 \%$ to $72 \%$ of serpentine, $26 \%$ to $40 \%$ of chromite and traces of talc, olivine, asbestos and iron oxides. Grain size range from 1 to $0.02 \mathrm{~mm}$. 

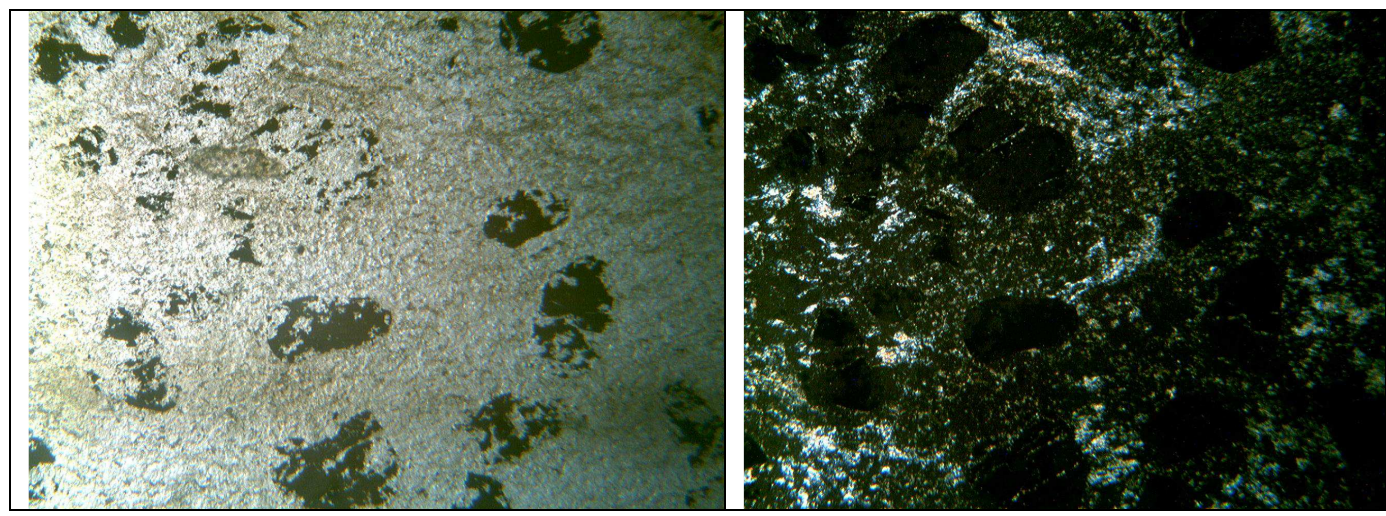

Fig.1: Highly disseminated and refractory chromite. The chromite crystals were subjected to restoration and dislocation in a serpentine ground mass thin section (XN, $4 \times 10)$

\subsection{Flotation characteristics of high grade chromite}

Figure 2 shows the chromite flotation recoveries as a function of various dosages of oleic acid at different $\mathrm{pH}$ values. The flotation results revealed that increasing the oleic acid dosage up to $3 \mathrm{~kg} / \mathrm{t}$ increases the recovery. Because the $\mathrm{pH}$ of the medium is an important factor in flotation, its effect was investigated. The higher flotation recoveries were attained at $\mathrm{pH} 11$, and this may be due the fact that ions $\mathrm{Al}^{3+}$ and $\mathrm{RCOO}^{-}$were predominant in the solution [Sobieraj,. and Laskowski, , 1973; Shibata and Fuerstenau, 2003].

The flotation of a high grade chromite using oleic acid as collector showed, that the chromite can be floated at collector dosages of between 0.2 and $2 \mathrm{~kg} / \mathrm{t}$.

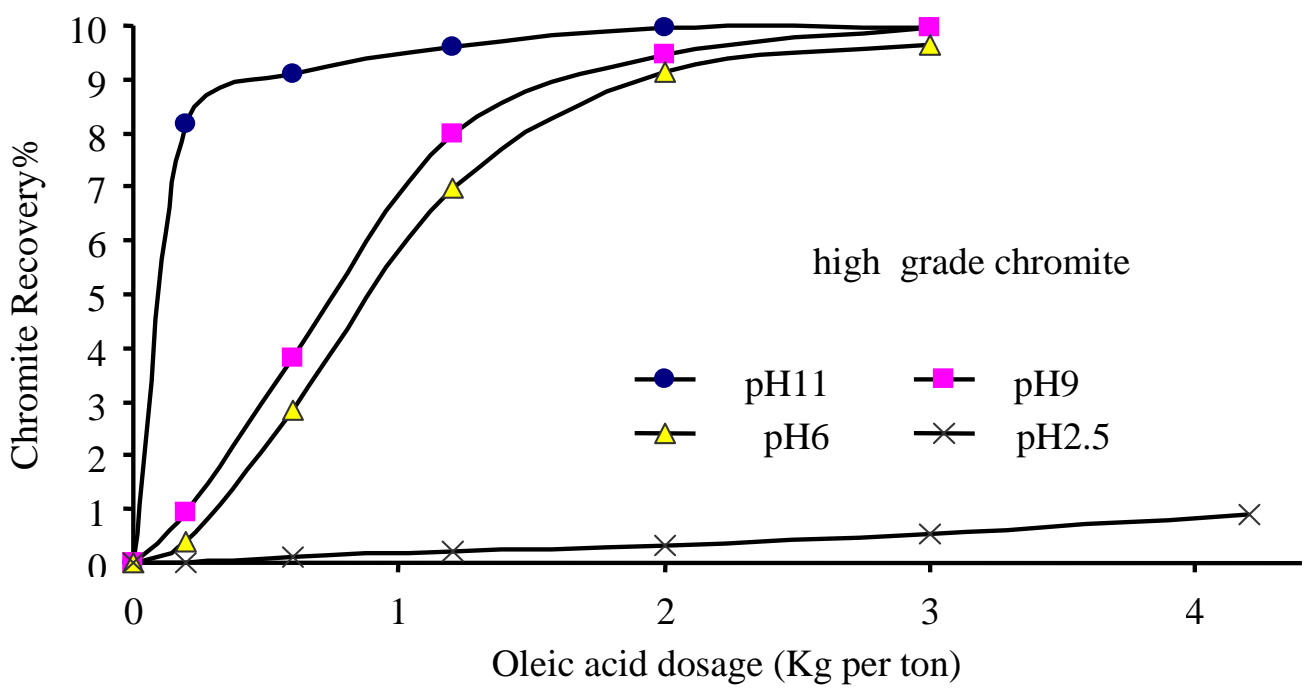

Fig.2: Flotation recoveries of chromite as a function of various dosages of oleic acid at $\mathrm{pH} 11 ; 9 ; 6$ and 2.5 


\subsection{Flotation of serpentine}

Figure 3 shows the serpentine flotation recoveries as a function of various dosages of oleic acid at $\mathrm{pH} 2.5 ; 6 ; 9$ and 11 . The flotation results revealed that increasing the oleic acid dosage increases the floatability of serpentine. The maximum flotation recovery using oleic acid was $94.6 \%$, which obtained at $\mathrm{pH} 11$ when $\mathrm{Al}^{3+}$ (may be from chlorite) and $\mathrm{RCOO}^{-}$is predominant in the solution. Flotation results show that the recovery increased with increasing collector dosage. From the above results it is clear that, both chromite and serpentine minerals have similar flotation characteristics, but the response of chromite to changes in $\mathrm{pH}$ and collector dosage is more sensitive than that of serpentine.

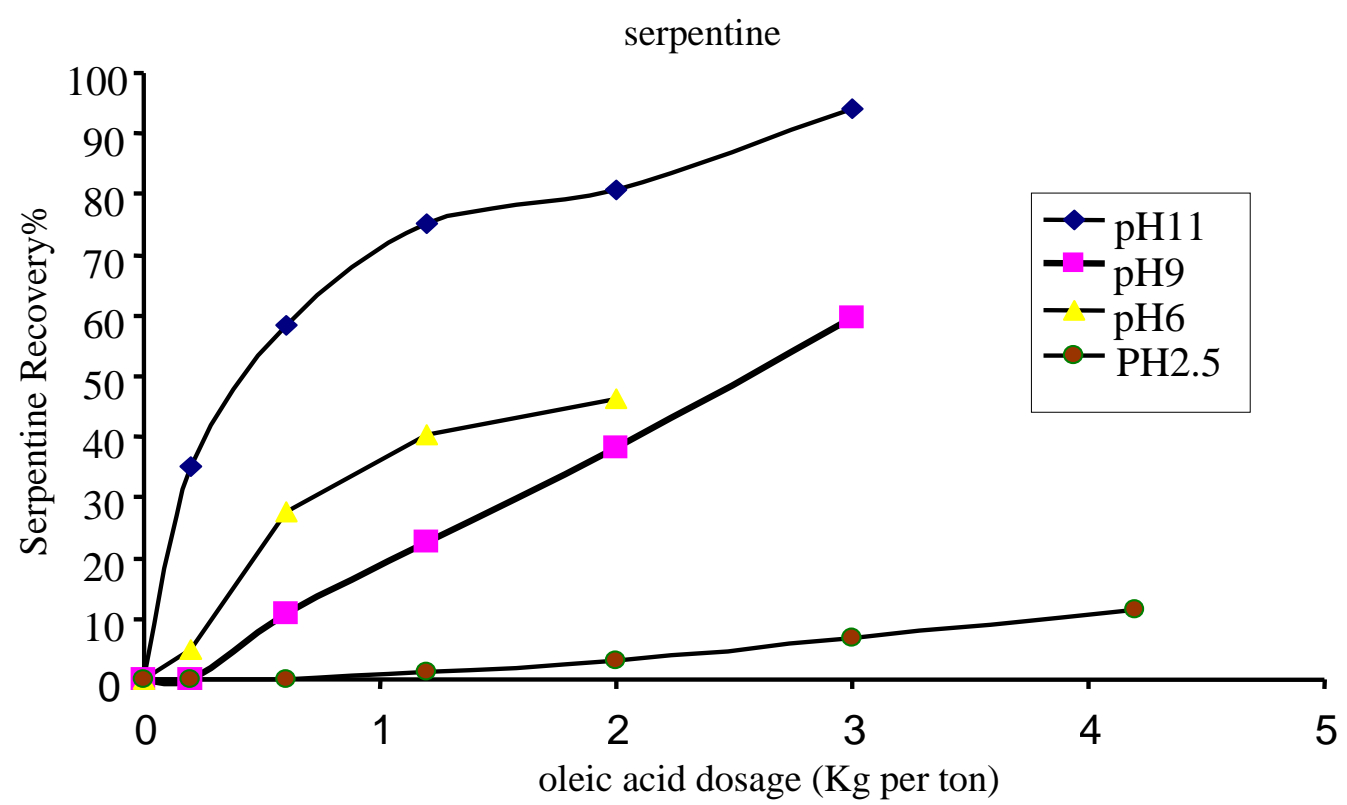

Fig.3: Flotation recoveries of serpentine as a function of various dosages of oleic acid at $\mathrm{pH} 11 ; 9 ; 6$ and 2.5 .

\subsection{Influence of $\mathrm{pH}$}

As shown in Fig.4, chromite floats in the presence of $200 \mathrm{~g} / \mathrm{t}$ oleic acid at $\mathrm{pH}$ region greater than 10 . However, it is shown that chromite floats better at $\mathrm{pH}$ greater than $\mathrm{pH}$ 9.5 in presence of $600 \mathrm{~g} / \mathrm{t}$ oleic acid [Palmer, et al, 1975.]. The lack of flotation recovery in the acidic $\mathrm{pH}$ range was attributed to adsorption of less surface active oleic acid $\left(\mathrm{RCOO}^{-}\right)$[Somasundaran and Wang, 2006]. Among the various ions that can be present in the pulp, $A l^{3+}$ ions which exert the most influence on the flotation behavior of chromites. These ions cause depression in the $\mathrm{pH}$ range 4.5 to 8 and activation between $\mathrm{pH} 10$ and 12 [Sobierag and Laskowski, 1973].

At $\mathrm{pH}$ from 2.5 to 6 , there is no difference in the floatability between chromite and serpentine. The results depicted in Fig.4, is in agreement with those reported by Havens (1946). 


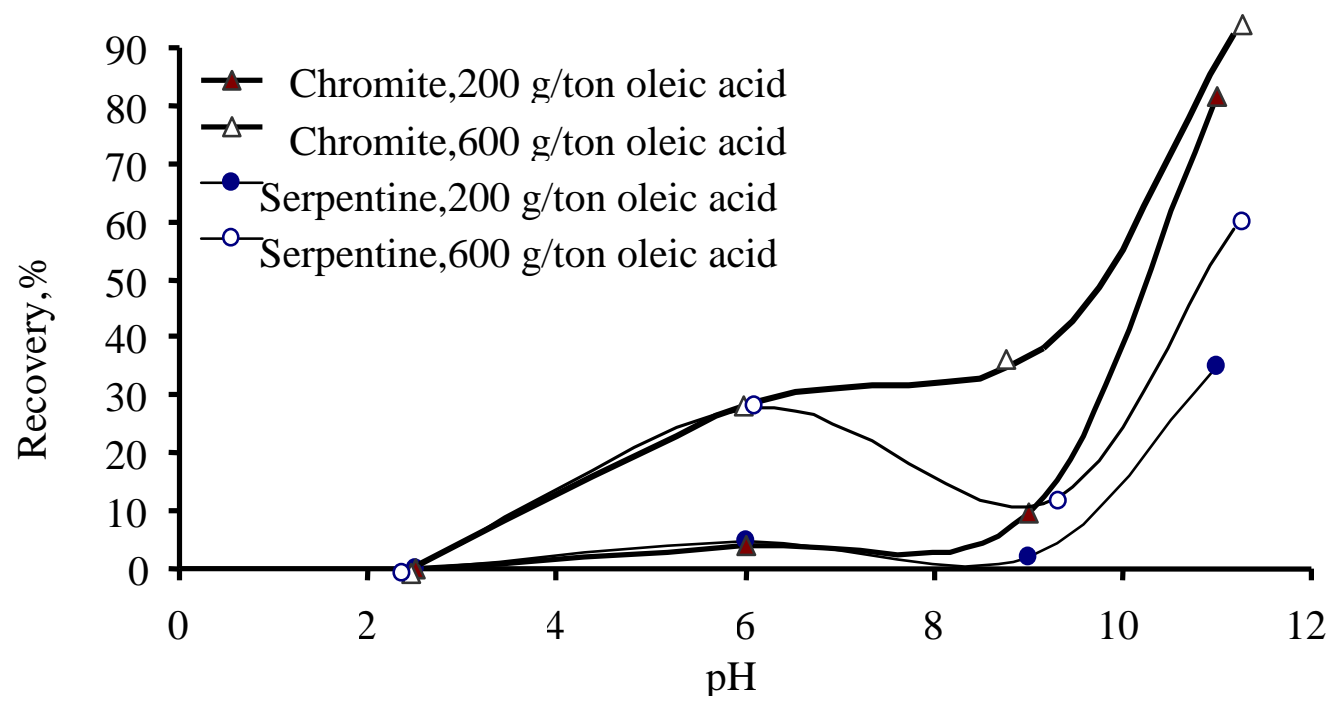

Fig.4: effect of $\mathrm{pH}$ on Recoveries of high grade chromite and serpentine at various oleic acid dosages.

\subsection{Effect of depressant dosage}

Figure 5 revealed that the addition of sodium silicate has significant depressing effect on chromite flotation at different $\mathrm{pH}$. As silicate dosage increases the flotation recovery of chromite decreases at $\mathrm{pH} 9$ and 11, which indicates the increase of adsorption of silicate on chromite surface in this $\mathrm{pH}$ range. Studies of the distribution of various silicate species as a function of $\mathrm{pH}$ have shown that silicic acid , $\mathrm{Si}(\mathrm{OH})_{4}$, and the monosilicate ions $\mathrm{SiO}(\mathrm{OH})_{3}^{-}$, predominate in the $\mathrm{pH}$ range 9 to 10 [Lagerstrom, 1959; Klassen and Krokhin, 1963].

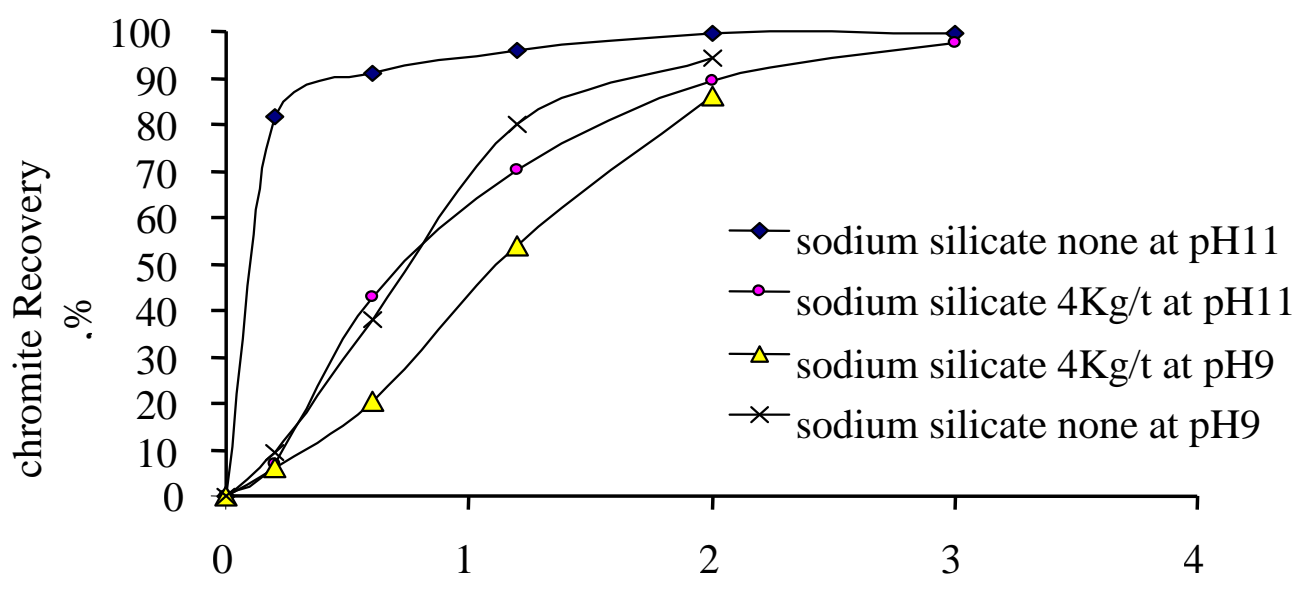

Oleic acid dosage $(\mathrm{kg} / \mathrm{t})$

Fig.5: Flotation recoveries of chromite as a function of various dosages of oleic acid in sodium silicate conc. none $\mathrm{kg} / \mathrm{t} ; 4 \mathrm{~kg} / \mathrm{t}$ at $\mathrm{pH} 9,11$. 
Figure 6 reveals that the floatability of serpentine decreased as a result of the addition of sodium silicate. It is stated by Lagerstrom, 1959; Klassen and Krokhin, 1963, that if the mineral surface is covered with highly polymerized silicate, it would be difficult for anionic collectors to adsorb on the surface of mineral and consequently the mineral surface will be strongly depressed. The mineral surface is covered with monomer silicates or colloidal amorphous silica particles of large size, the coverage will be incomplete and attachment becomes weaker. Therefore, it is less difficult for the oleate to adsorb onto the surface and make the surface hydrophobic.

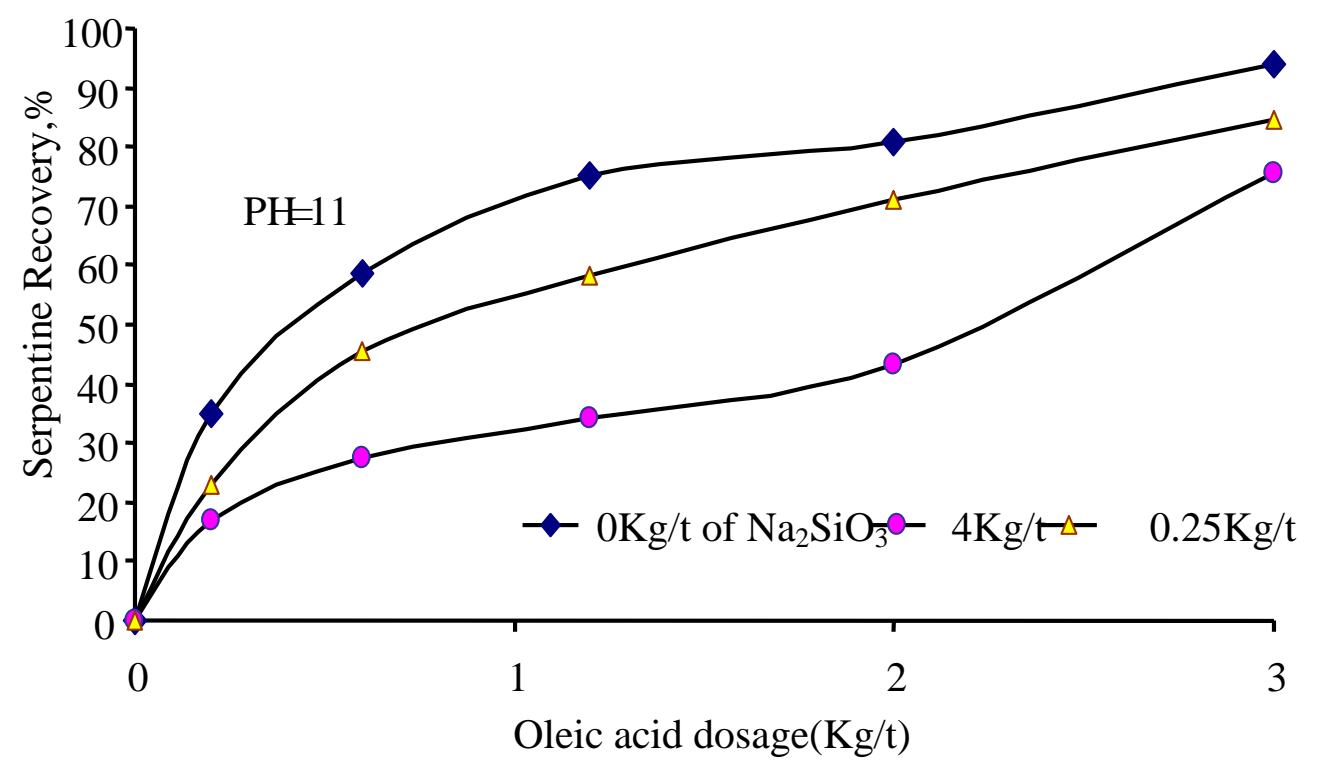

Fig.6: Flotation recoveries of serpentine as a function of various dosages of oleic acid in sodium silicate dosage of $0 \mathrm{Kg} / \mathrm{t} ; 0.25 \mathrm{Kg} / \mathrm{t} ; 4 \mathrm{Kg} / \mathrm{t}$ at $\mathrm{pH} 11$.

Using of sodium silicate $(4 \mathrm{~kg} / \mathrm{t})$ as a depressant indicated a somewhat similar

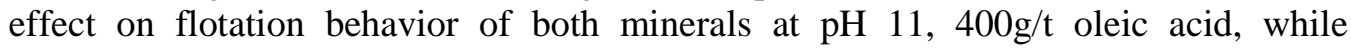
increasing oleic acid concentration more than $400 \mathrm{~g} / \mathrm{t}$ increased the difference in their floatability markedly (Fig.7).

\subsection{Effect of conditioning time}

Studies to date have revealed that conditioning time plays an important role in serpentine flotation. Tests conducted to determine the influence of conditioning time on flotation behavior of high grade samples yielded some what surprising results. It can be seen from Fig.8, that the rate of increase of the flotation recovery of serpentine as a function of collector dosage increases with the increase in conditioning time at a rate higher than that of all conditioning times tested. 


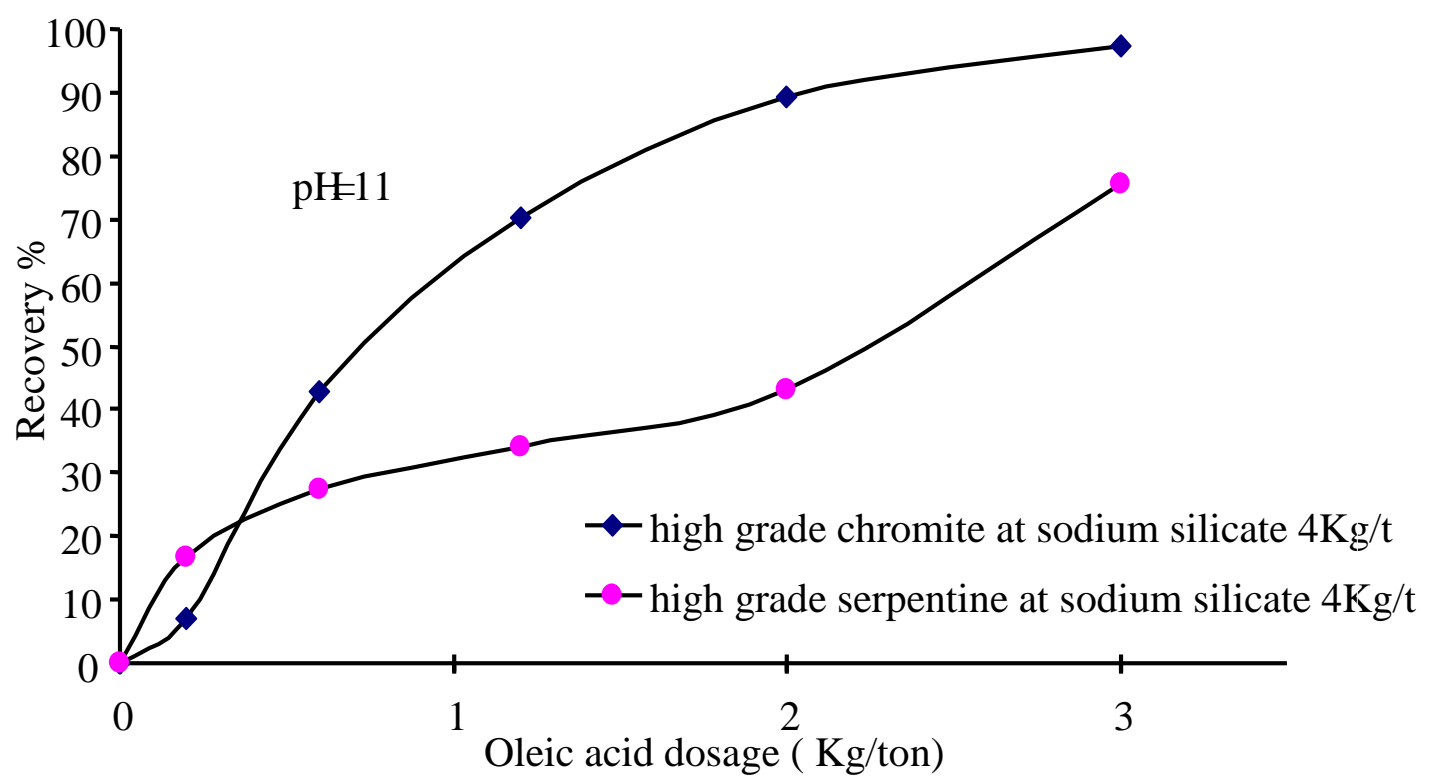

Fig.7: Flotation recoveries of serpentine and chromite as a function of various dosages of oleic acid in sodium silicate dosage of $4 \mathrm{Kg} / \mathrm{t}$ at $\mathrm{pH} 11$

\subsection{Flotation of low grade chromite ore}

The optimum conditions obtained from the flotation of high grade chromite and clean serpentine minerals were applied to the flotation of the low grade chromite ore sample.

Low grade chromite ore (containing $20.27 \% \mathrm{Cr}_{2} \mathrm{O}_{3}$ and ground to pass $\% 100$ $180 \mu \mathrm{m})$ was used in the flotation tests using the 2-liter flotation machine.

Flotation test conditions were: Feed size $-180 \mu \mathrm{m}$, pulp density of $20 \%$ solids for conditioning and flotation, wetting time of 5 minutes, $\mathrm{pH} 9$, and addition of collector $(300 \mathrm{~g} / \mathrm{t}$ of Oleic acid), condition time of collector for $2 \mathrm{~min}$, and flotation time $3 \mathrm{~min}$. The results are shown in Table 3.

Table 3: result of rougher flotation of ore sample \% $100-180 \mu \mathrm{m}$

\begin{tabular}{|l|c|c|c|c|}
\hline Fraction & weight & Weight \% & $\mathbf{C r}_{\mathbf{2}} \mathbf{O}_{\mathbf{3}} \%$ & Recovery\% \\
\hline Froth product & 133 & 33.25 & 3.33 & 5.46 \\
\hline Sink product & 267 & 66.75 & 28.71 & 94.54 \\
\hline Feed & 400 & 100.00 & 20.27 & 100.00 \\
\hline
\end{tabular}




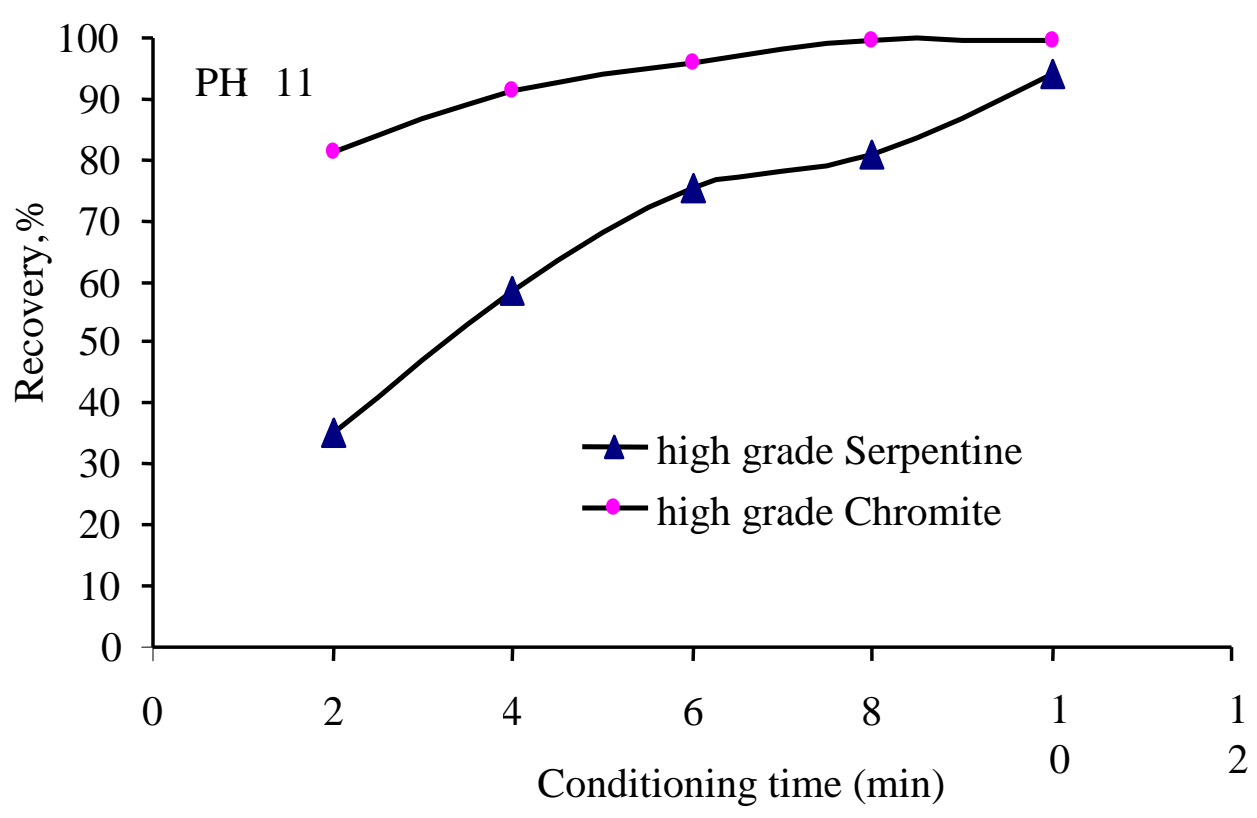

Fig.8: Effect of conditioning time on the flotation performance of chromite and serpentine.

The results shown in Table 3 shows different flotation behavior from that obtained in flotation of pure chromite and serpentine minerals. This could be attributed to the following reasoning. Thepresence of chlorite mineral (rich in aluminum), as one of the gangue minerals in the low-grade chromite ore, may be the reason for this exceptional behavior (reverse behavior) in flotation between high-grade chromite and high-grade serpentine flotation systems and the low-grade flotation system. The chlorite releases excess amount of $\mathrm{Al}^{+3}$ ions in the system which preferably replaces the $\mathrm{Mg}^{+2}$ on the serpentine surface rendering the serpentine surface more positive than the chromite surface. In this case, the anionic species, $\mathrm{RCOO}^{-}$, absorbs preferentially on the serpentine surface, rather than the chromite surface, causing the serpentine to float. Mean while, the depressant species silicic acid and/or the monosilicic ions are adsorbed on the chromite surface, and hence chromite is depressed. Figure 9 shows a schematic representation for a serpentine particle before and after the ionic exchange of $\mathrm{Al}^{+3}$ and $\mathrm{Mg}^{+2}$ on the serpentine surface.

\section{CONCLUSIONS}

- Ingassana hills area consists of different chromite deposits assaying 23\% $\mathrm{Cr}_{2} \mathrm{O}_{3}$, which classified as low grade ore. The ore minerals from these deposits were similar in their mineralogical characteristics.

- The major minerals are chromite and serpentine .Olivine, iron oxides and talc have been identified as minor minerals.

- A reasonable degree of liberation of chromite minerals from their gangue could be obtained by size reduction to $-0.180 \mathrm{~mm}$. 


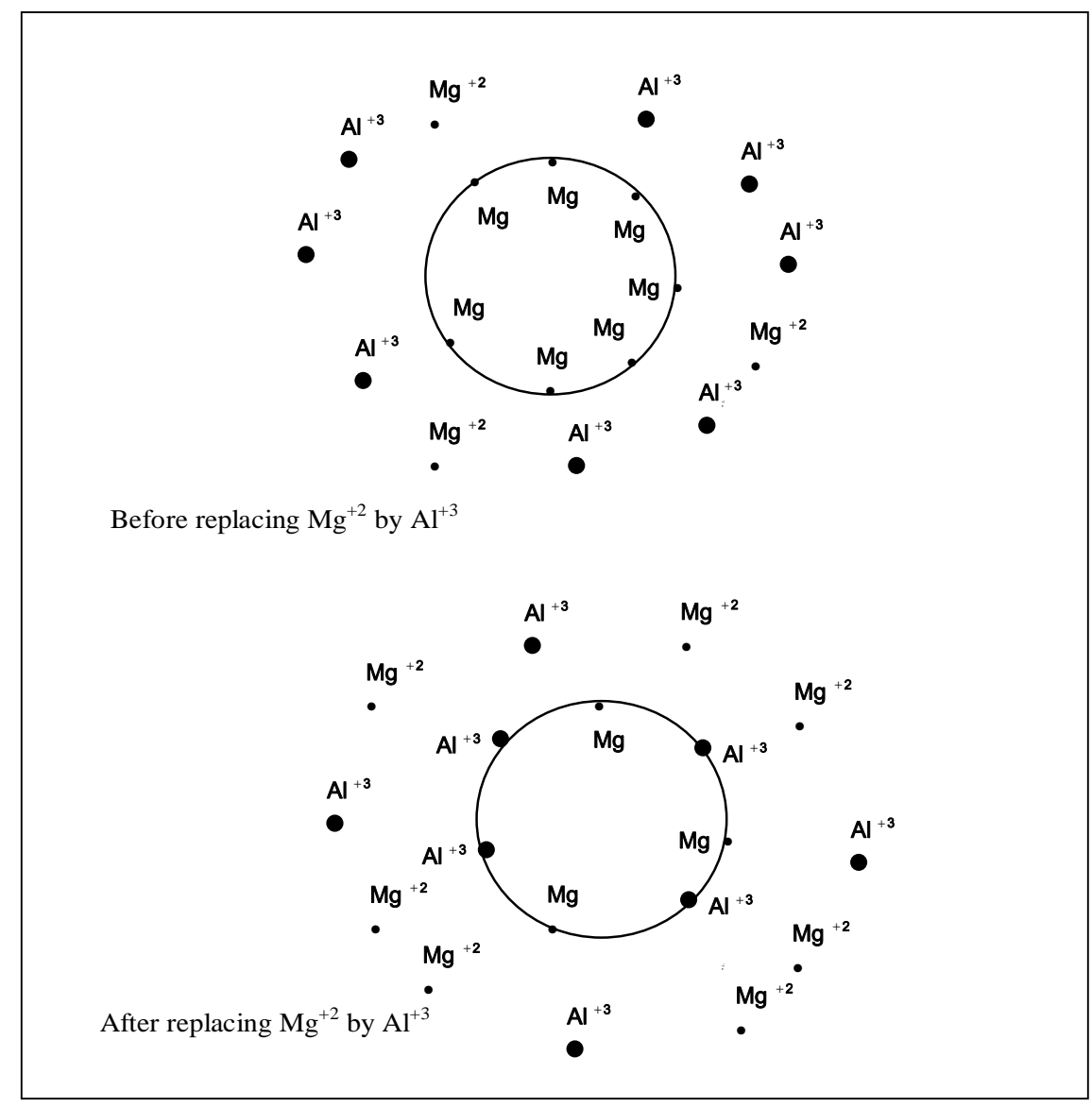

Fig. 9 A schematic representation of the ionic exchange of $\mathrm{Al}^{+3}$ and $\mathrm{Mg}^{+2}$ on the serpentine surface.

- Flotation recoveries of chromite and serpentine increased with increasing collector concentration.

- Using sodium silicate as depressant indicated a somewhat similar effect on flotation behavior of both minerals.

- The optimum conditioning time of oleic acid was found to be 2 minutes.

- A concentrate of $28.71 \% \mathrm{Cr}_{2} \mathrm{O}_{3}$ with recovery of $94.54 \%$ from a feed assay $20.27 \% \mathrm{Cr}_{2} \mathrm{O}_{3}$ was obtained.

\section{REFERENCES}

1. Adli A.M .Ahmed, 1998, Sudan industrial minerals and rocks, centre for strategic studies, Khartoum- Sudan, pp.76-86.

2. Havens, R., 1946, Froth flotation of chromite with fluoride. U.S.Patent: 2,412,217. pp. 7

3. Hunter, W. L., and Sullivan. V., 1960, Utilization studies on chromite from Seiad Creek, Calif. U.S. Bureau of Mines, Report of Investigations 5576, pp. 37 
4. Klassen W.I. and Krokhin S.I., 1963, contribution to the mechanism of action of flotation reagents, mineral processing, proceeding of the sixth international congress, Cannes, 1963, pp.397-406.

5. Koster, J., 1936, Studies on the treatment of domestic chrome ores. U.S. Bureau of Mines, Report of Investigations 3322, pp. 37.

6. Lagerstrom, B., 1959 , Acta chemica scandinvica, vol.13, p.722.

7. Palmer B. R., Fuerstenau M.C., Aplan F.F., 1975, Mechanism involved in the flotation of oxides and silicates with anionic collectors. Part 2. Trans. AIME, 258, p.261.

8. Pyor E. J., 1965, Mineral processing, third edition , Amsterdam, London-New York.

9. Ralph H. Nafziger, 1982, A review of the deposits and beneficiation of lowergrade chromite, Journal of the South African Institute of Mining and Metallurgy, pp. 205-226.

10. Read, H.H., 1956, "Rutley's Elements of Mineralogy", $24^{\text {th }}$ Edition, Thomas Murby \& Co., London, pp. 409.

11. Sagheer, M. 1966. Flotation characteristics of chromite and serpentine. Trans. AIME, vol. 235, no. 1. pp. 60 - 67.

12. Shibata J., and Fuerstenau, D.W., 2003, "flocculation and flotation characteristics of fine hematite with sodium oleate", International Journal of Mineral Processing, 72, pp.30

13. Sobieraj, S. and Laskowski, J., 1973, Flotation of chromite Trans. Instn Min. Metall. Section C, vol. 82, no. 805. pp. C207 - C213. (http://www.freepatentsonline.com/4311584.html). 30/11/2007.

14. Somasudaran,P., and Wang, Dianzuo ,2006, solution chemistry :minerals and reagents ,Elsevies publisher, Development in mineral processing 17,pp.18-22

15. U.S. Pat. No. 3,473,656 (http://www.freepatentsonline.com/4311584.html) Chem. Absts., 78, 1973, 128755 C. 


\section{سلوك خامات الكروميث السودانية عند التعويم}

هذا البحث يهنم بمعالجة ، خامات الكروميت السودانية من جبال الاتقسنا حيث تم الفحص المعدنى وتحديد الخصائصَ المعدنية والفيزيائية قبل التركيز و دراسة امكانية معالجة خام الكرومايت بواسطة

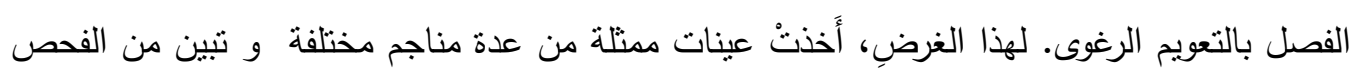

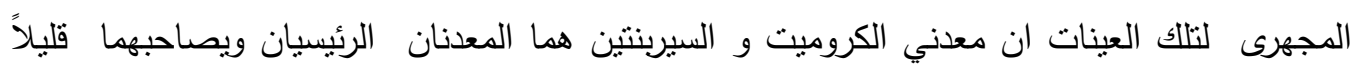

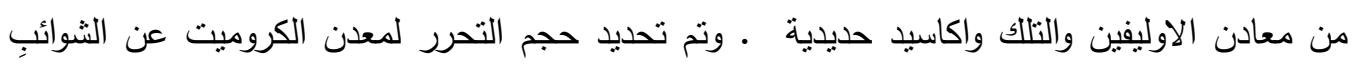

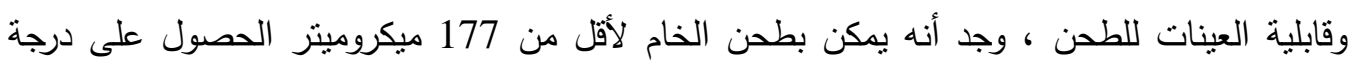
تحرر عالية(83.4 \%) لمعدن الكرومايت عن الثوائب المصاحبة للخام.

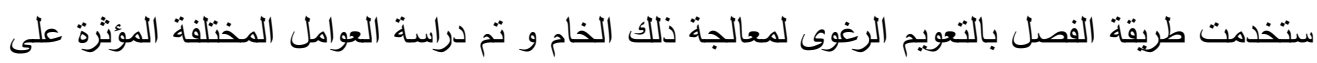

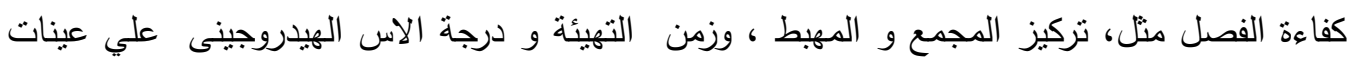

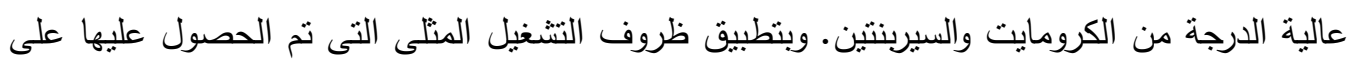
خام كروميت منخفض الدرجة تم الحصول على ركاز يحتوى على 28.71\% اكسيد الكروم و نسبة

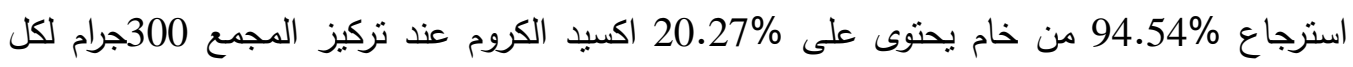
طن، وزمن التهيئة دقيقتان و درجة الاس الهيدروجينى الطبيعى(2049) و نسبة المادة الصلبة إلى على

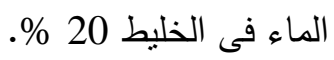

